University of Nebraska - Lincoln

DigitalCommons@University of Nebraska - Lincoln

\title{
Acoustic Stratigraphy of Bear Lake, Utah-Idaho-Late Quaternary Sedimentation Patterns in a Simple Half-Graben
}

Steven M. Colman

U.S. Geological Survey, 384 Woods Hole Rd., Woods Hole, MA 02543, United States

Follow this and additional works at: https://digitalcommons.unl.edu/usgsstaffpub

Part of the Earth Sciences Commons

Colman, Steven M., "Acoustic Stratigraphy of Bear Lake, Utah-Idaho-Late Quaternary Sedimentation Patterns in a Simple Half-Graben" (2006). USGS Staff -- Published Research. 276.

https://digitalcommons.unl.edu/usgsstaffpub/276

This Article is brought to you for free and open access by the US Geological Survey at DigitalCommons@University of Nebraska - Lincoln. It has been accepted for inclusion in USGS Staff -- Published Research by an authorized administrator of DigitalCommons@University of Nebraska - Lincoln. 


\title{
Acoustic stratigraphy of Bear Lake, Utah-Idaho-Late Quaternary sedimentation patterns in a simple half-graben
}

\author{
Steven M. Colman* \\ U.S. Geological Survey, 384 Woods Hole Rd., Woods Hole, MA 02543, United States
}

Received 25 February 2005; received in revised form 11 November 2005; accepted 18 November 2005

\begin{abstract}
A 277-km network of high-resolution seismic-reflection profiles, supplemented with a sidescan-sonar mosaic of the lake floor, was collected in Bear Lake, Utah-Idaho, in order to explore the sedimentary framework of the lake's paleoclimate record. The acoustic stratigraphy is tied to a $120 \mathrm{~m}$ deep, continuously cored drill hole in the lake. Based on the age model for the drill core, the oldest continuously mapped acoustic reflector in the data set has an age of about $100 \mathrm{ka}$, although older sediments were locally imaged.

The acoustic stratigraphy of the sediments below the lake indicates that the basin developed primarily as a simple half-graben, with a steep normal-fault margin on the east and a flexural margin on the west. As expected for a basin controlled by a listric master fault, seismic reflections steepen and diverge toward the fault, bounding eastward-thickening sediment wedges. Secondary normal faults west of the master fault were imaged beneath the lake and many of these faults show progressively increasing offset with depth and age. Several faults cut the youngest sediments in the lake as well as the modern lake floor. The relative simplicity of the sedimentary sequence is interrupted in the northwestern part of the basin by a unit that is interpreted as a large $(4 \times 10 \mathrm{~km})$ paleodelta of the Bear River. The delta overlies a horizon with an age of about $97 \mathrm{ka}$, outcrops at the lake floor and is onlapped by much of the uppermost sequence of lake sediments. A feature interpreted as a wave-cut bench occurs in many places on the western side of the lake. The base of this bench occurs at a depth (22-24 m) similar to that (20-25 m) of the distal surface of the paleodelta.

Pinch-outs of sedimentary units are common in relatively shallow water on the gentle western margin of the basin and little Holocene sediment has accumulated in water depths of less than $30 \mathrm{~m}$. On the steep eastern margin of the basin, sediments commonly onlap the hanging wall of the East Bear Lake Fault. However, no major erosional or depositional features suggestive of shoreline processes were observed on acoustic profiles in water deeper than about 20-25 m.
\end{abstract}

(C) 2005 Elsevier B.V. All rights reserved.

Keywords: Bear Lake; Seismic-reflection profiles; Graben; Faulting; Sedimentation

\section{Introduction}

Lacustrine sediments in rift basins have considerable scientific and economic importance, and acoustic meth-

\footnotetext{
* Present address: Large Lakes Observatory and Dept. Geological Sciences, University of Minnesota Duluth, 2205 E. 5th St., Duluth, MN 55812, United States. Fax: +1 2187266979.

E-mail address: scolman@d.umn.edu.
}

ods (seismic-reflection and sidescan-sonar data) are some of the primary tools for studying rift-basin sedimentation and structure. Acoustic-stratigraphic studies of modern rift-basin lakes have mostly been conducted in large lakes within complex rift systems such as the East African Rift (e.g., Johnson et al., 1987; Lezzar et al., 1996; Scholz et al., 1993) and the Baikal Rift (e.g., Colman et al., 2003; Moore et al., 1997; Scholz and Hutchinson, 2000). These rift systems typically com- 
prise multiple complex basins separated by structurally complicated accommodation zones. In contrast, Bear Lake in Utah and Idaho (Fig. 1) is situated within a relatively small, single half-graben. The lake thus affords an opportunity to study rift-basin sedimentation in arguably its simplest configuration.

The Bear Lake Basin (Fig. 1) is located at the southern end of the larger Bear Lake Valley, extending northward near the northeastern margin of the basin and range province, at its boundary with the Colorado Plateau. The Bear River Range, to the west of the lake, is mostly underlain by Paleozoic carbonate rocks, in which a karst drainage is well developed, presumably contributing large amounts of groundwater to the lake. To the east of the lake is the Bear Lake Plateau, mostly underlain by Tertiary continental rocks.

The long-term tectonic history of the area is complex, beginning with Laramide foreland thrusting, followed by a reversal of stress with the development of extensional Basin and Range structures. Major studies of the bedrock and surficial geology of the area include Williams and others (1962), Kaliser (1972) and Dixon

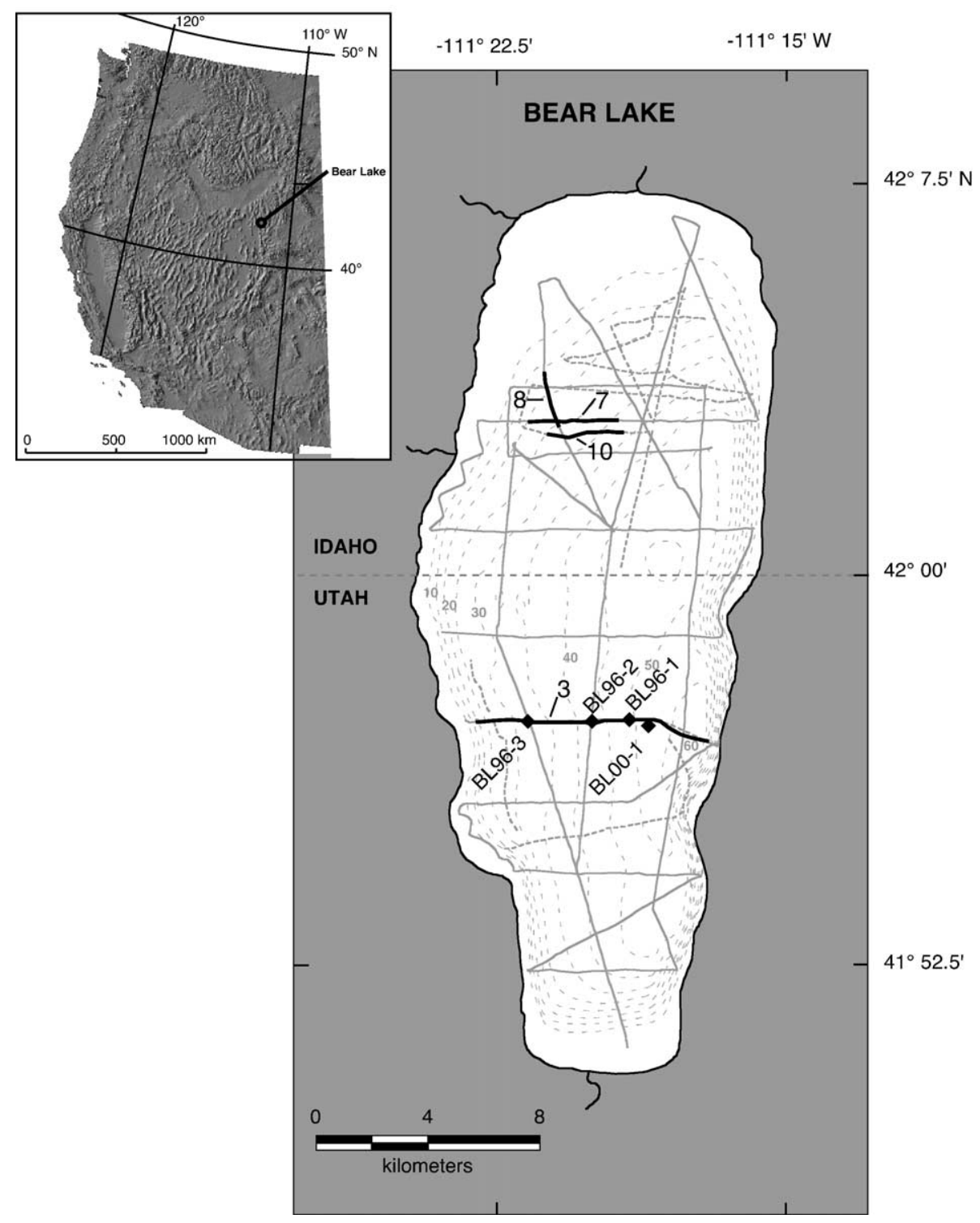

Fig. 1. Map of Bear Lake showing location of acoustic-reflection profiles. Bathymetric contour interval $5 \mathrm{~m}$, beginning with $10 \mathrm{~m}$. Heavy lines with numbers show the location of profiles illustrated in the figures corresponding to the numbered labels. Diamonds indicate core locations, from east to west, BL00-1, and BL96-1, -2 and -3. Inset: western United States location map for Bear Lake. 


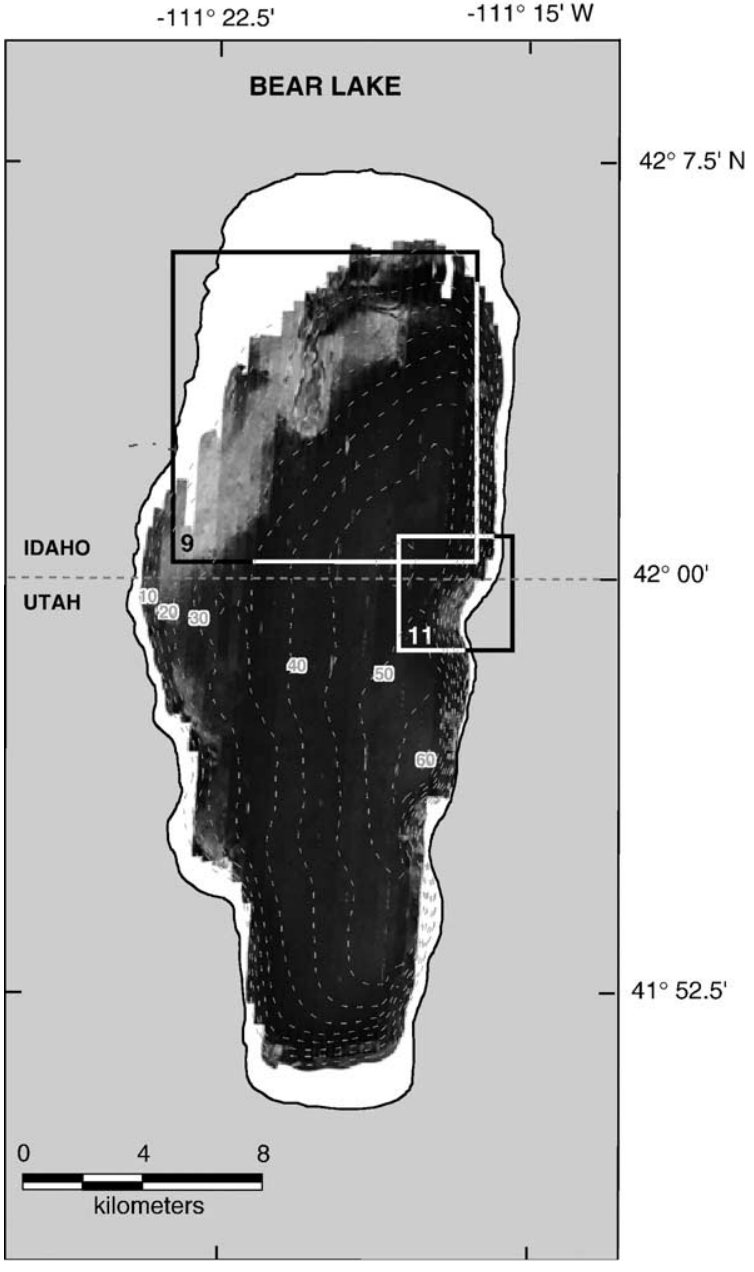

Fig. 2. Sidescan-sonar mosaic of the floor of Bear Lake. Bathymetric contour interval $5 \mathrm{~m}$, beginning with $10 \mathrm{~m}$. Boxes with numbers in their lower left corners show the location of images illustrated in the corresponding figures.

(1982). On the basis of surficial geology, limited borehole data and unpublished industry seismic data, Evans et al. (2003) interpreted the deep structure of the Bear Lake Valley in the context of historical earthquake activity, and produced a balanced cross section just north of the lake. The tectonic history of the Bear Lake Basin was reviewed by McAlpin (1993, 2003), who showed that the area is seismically active, as evidenced by displaced Holocene strata and several historical earthquakes (McCalpin, 2003).

The overall structure of the basin, as reflected by both the bathymetry of Bear Lake (Denny and Colman, 2003) and the pattern of deposition of its sediments (described here), is that of an eastward tilting half-graben, controlled by a master normal fault along the east margin of the lake. This fault, the East Bear Lake Fault, is steep at the surface and becomes listric at depth, soling in one of

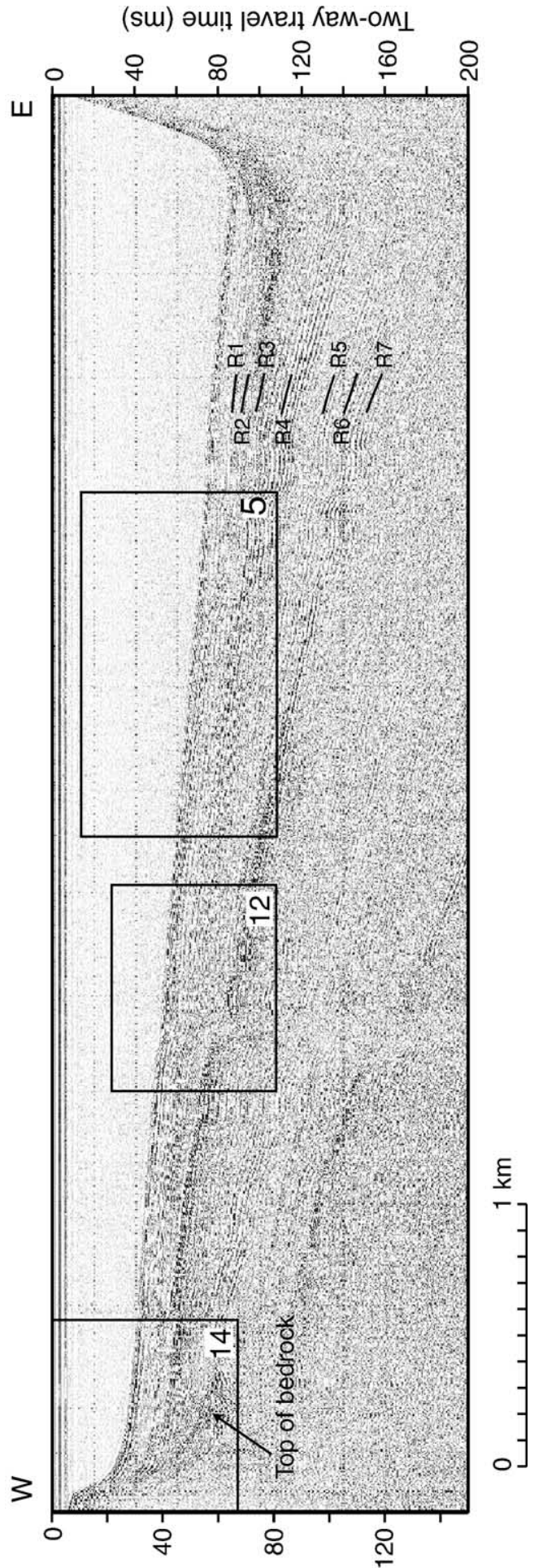

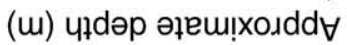




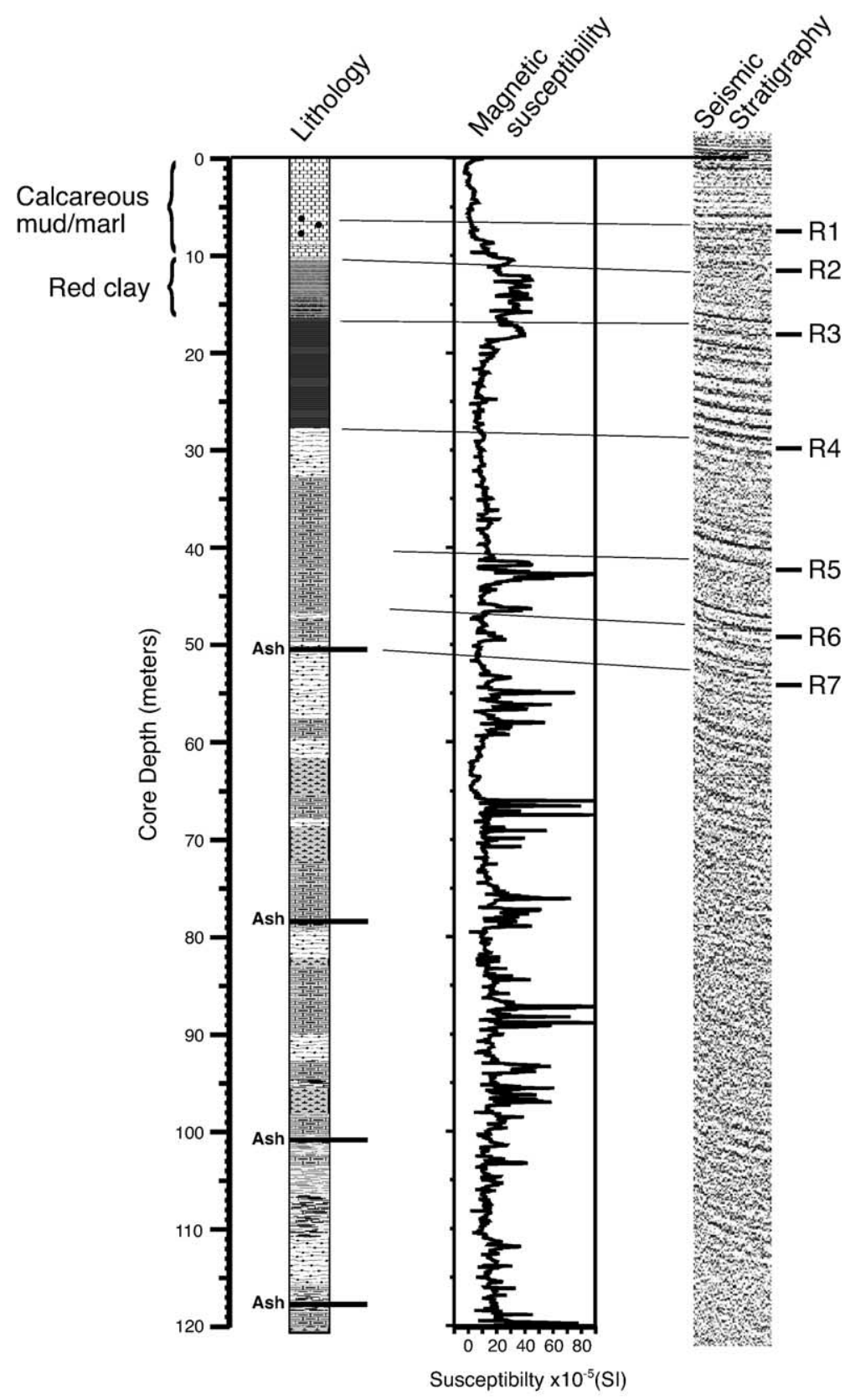

\section{Bear Lake Core BL00-1E}

Fig. 4. Correlation among the lithology of BL00-1E, magnetic susceptibility (C. Heil, written commun., 2001) and the acoustic-reflection data (boomer system) at the site.

the Laramide thrusts (Evans et al., 2003). Extension accommodated by this listric fault has formed a basin containing about $3 \mathrm{~km}$ of Tertiary and Quaternary sediment, which is underlain by thrusted Paleozoic and Mesozoic sedimentary rocks (Evans et al., 2003). The East Bear Lake Fault has experienced four to six epi- sodes of normal faulting in the last 40,000 years, the youngest of which occurred about 2500 years ago (McCalpin, 2003). The western margin of the graben is largely flexural, but it is also marked by normal faults (the West Bear Lake Fault zone), which experienced movement as recently as about 7000 years ago (McCal- 


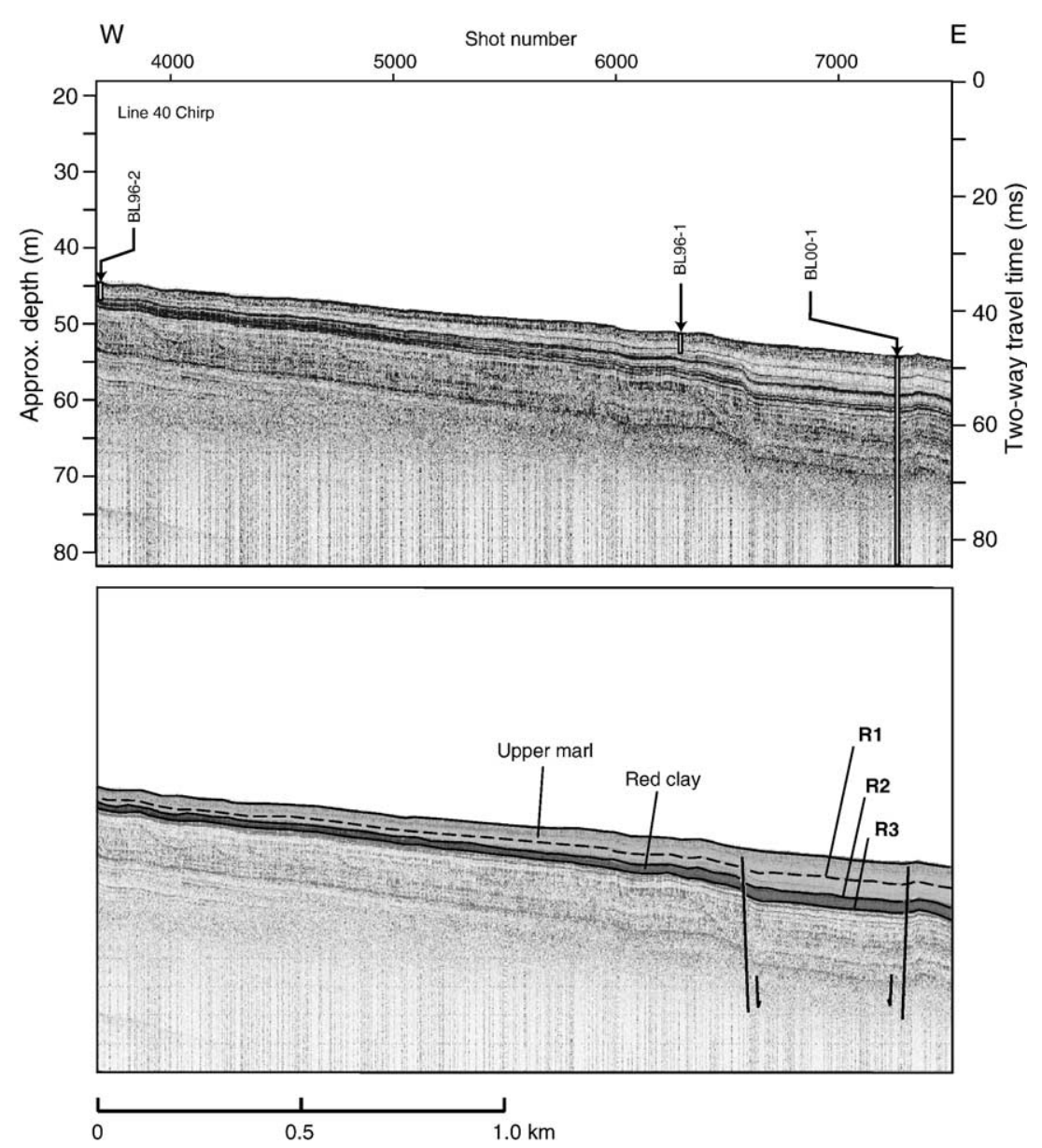

Fig. 5. Acoustic profile (chirp system) along the segment of line 40 containing the core sites BL96-1, BL96-2 and BL00-1. In lower panel, light gray represents post-glacial marl and dark gray represents late-glacial red lacustrine mud. Location shown in Fig. 3.

pin, 2003). The West Bear Lake Fault zone is interpreted as a series of antithetical faults in the footwall of the East Bear Lake Fault and one of these antithetical faults is thought to be the source of the 1884 M 6.3 Bear Lake earthquake (Evans et al., 2003).

Historically, Bear Lake was a closed basin, fed by relatively small local streams and groundwater input. Significant groundwater throughflow presumably accounts for the lake's oligotrophic, mesosaline character (Dean et al., 2006-this volume). At this time, the Bear River, which enters the Bear Lake Valley transversely just north of the lake, flowed northward and did not enter the lake. The river was partially diverted into the lake through a series of canals completed in 1918 that allowed the lake to be used as a water-storage reservoir.

At various times in the past, the lake overflowed naturally, as its level fluctuated considerably, as much as $11 \mathrm{~m}$ above its present nominal elevation of $1805 \mathrm{~m}$ (Laabs and Kaufman, 2003). In addition, the composition of sediments in the lake indicate that the Bear River flowed naturally into Bear Lake several times in the past (Dean et al., 2006 - this volume), at which times it presumably overflowed as well.

One previous seismic-reflection study has been conducted in Bear Lake (Skeen, 1975). This study used a somewhat lower frequency sound source $\left(1 \mathrm{in.}^{3}\right.$ air gun), which consequently provided data with deeper penetration but lower resolution compared to the data discussed here. The general configuration of the upper part of the sedimentary sequence shown in Skeen's (1975) profiles appears similar to that in profiles shown here, although Skeen's interpreted depth to bedrock (maximum sediment thickness of $387 \mathrm{~m}$ ) is incompatible with Evans et al.'s (2003) estimate of 3 $\mathrm{km}$ for the depth of the sedimentary basin.

\section{Data and methods}

We collected about $202 \mathrm{~km}$ of high-resolution reflection data from Bear Lake in 1997 (Fig. 1). The 1997 data 


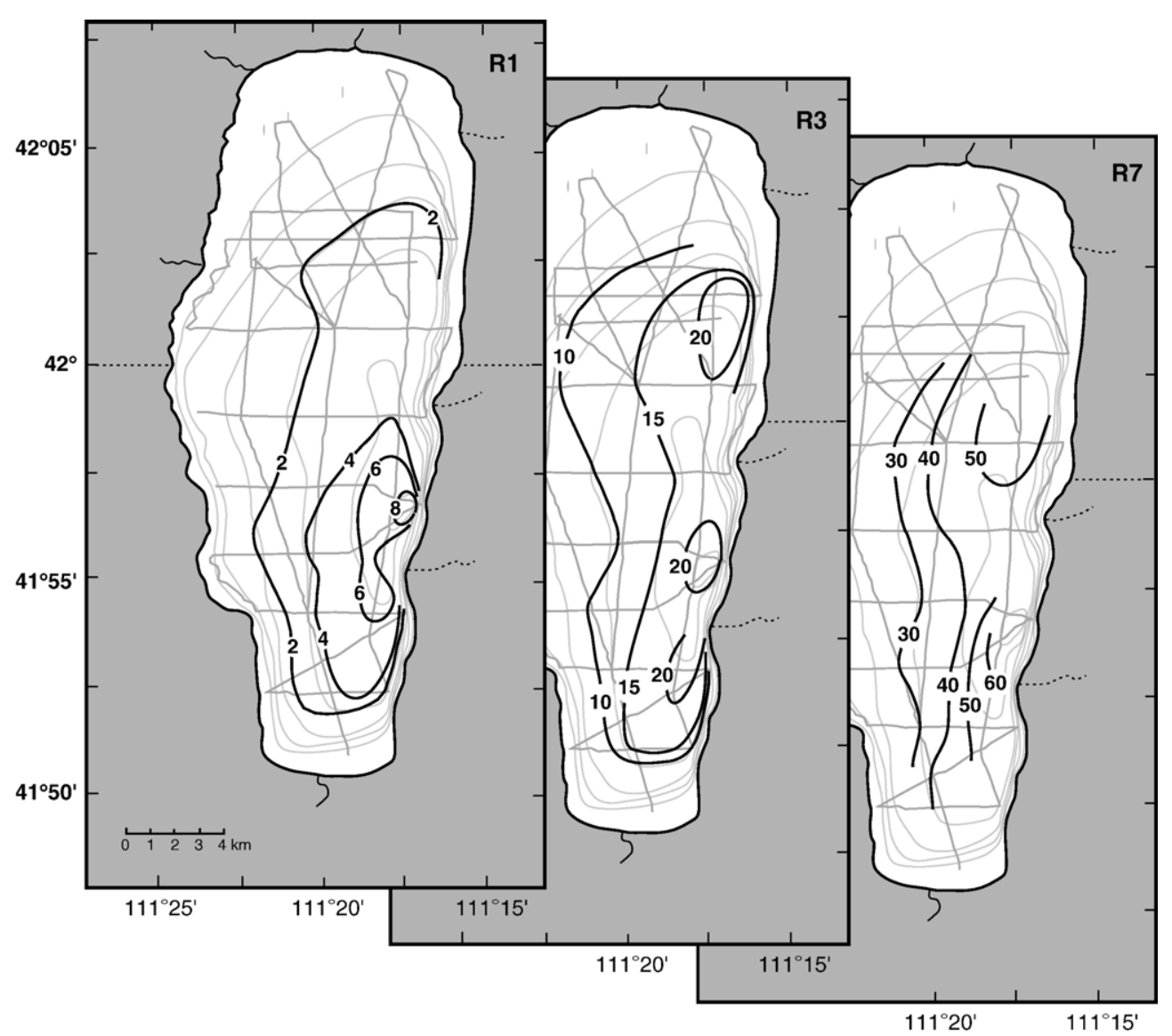

Fig. 6. Maps of total sediment thickness (in meters) above reflectors R1, R3 and R7, calculated using an assumed sound velocity of $1500 \mathrm{~m} / \mathrm{s}$. Contours (thick lines) in meters. Bathymetry $(10 \mathrm{~m}$ interval) and tracklines are shown as thin lines.

were collected using two systems: (1) a side-mounted array of four $\mathrm{ORE}^{1} 3.5 \mathrm{kHz}$ transducers, two sending the signal and two receiving the returns; and (2) a broad-band ("boomer") system, consisting of a Huntec 1 acoustic plate, an ITI $^{1} 10$-element hydrophone streamer and an $\mathrm{ORE}^{1} 140$ receiver/amplifier. In 2002, an additional $75 \mathrm{~km}$ of data were collected using a $4-24 \mathrm{kHz}$ Edgetech ${ }^{1} 424$ pulsed frequency ("CHIRP”) system (Fig. 1). All data were recorded digitally in SEG-Y format using a Delph Elics ${ }^{1}$ recording system. The seismic data were collected when the lake was about $4 \mathrm{~m}$ below its nominal lake-surface elevation of $1805.5 \mathrm{~m}$. Depths discussed in connection with the seismic profiles relate to the lake elevation at the time the data were collected.

Sidescan-sonar data were collected in 2002 for most of the lake floor deeper than $5 \mathrm{~m}$ using an Edgetech ${ }^{1}$ DF-1000 dual-frequency $(100 / 500 \mathrm{kHz})$ system (Denny

\footnotetext{
${ }^{1}$ Use of trade names is for informational purposes only and does not imply endorsement by the U.S. Geological Survey.
}

and Colman, 2003). The data were acquired using a $400 \mathrm{~m}$ swath width. These data were logged digitally at a $2 \mathrm{kHz}$ sample rate using Triton-Elics ISIS $^{1}$ acquisition package. The data were then processed using USGS software packages XSonar and ShowImage to correct geometric distortions inherent in the sidescan-sonar data. Geomatica ${ }^{1}$ Software Solutions was used to generate a sidescan-sonar mosaic (Fig. 2).

The geophysical data were located with militarygrade GPS (3 m accuracy) in 1997 and with differential GPS in 2002.

\section{Acoustic stratigraphy}

Penetration of the boomer data was generally in the range of $50-100 \mathrm{~m}$ and line 28 , a mid-lake dip line, is representative of the overall stratigraphy and structure (Fig. 3). Two long drill cores, the deepest of which (BL00-1E) was $120 \mathrm{~m}$ long, were drilled adjacent to line 28 (Dean et al., 2002) and provide lithological correlations (Fig. 4) for the acoustic stratigraphy. 
The general lithologic sequence in the cores consists of an upper tan marl and gray calcareous mud, deposited since about $17 \mathrm{ka}$, underlain by a red lacustrine clay, deposited before $17 \mathrm{ka}$ (Dean et al., 2006-this volume). In the 2000 drill core, the red mud is underlain by a variety of lithologies, all of which appear to represent deep lake sediments deposited under a variety of climatic conditions. Distinct, high-amplitude reflections (not necessarily sequence boundaries) in the acoustic data appear to correlate with major lithologic changes in the drill core (Fig. 4). In particular, R2 correlates with the base of the uppermost calcareous unit and R3 correlates with the base of the red clay (Fig. 4). Age information for the drill core (Colman et al., in press) indicates a long-term sedimentation rate of about $0.5 \mathrm{~m} / \mathrm{kyr}$ with some variation near the top of the core. The age of the base of the drill core is thus about 250 $\mathrm{ka}$, and the deepest continuously mapped reflector (R7), at $51 \mathrm{~m}$, is about $100 \mathrm{ka}$ old ( $97 \mathrm{ka}$ by the age model of Colman et al., in press).

The east-west acoustic-reflection lines are approximately parallel to the dip of the lacustrine sedimentary units and perpendicular to the recently active faults. The overall pattern is one of eastward dipping and eastward thickening beds, which pinch-out on the western margin of the lake and onlap the uplifted eastern margin (Fig. 3). Details of the eastward thickening sequences are most apparent in the high-resolution CHIRP data (Fig. 5). Onlap geometries are common on the east margin of the basin, where the lacustrine sequence is being deposited against what is essentially the fault scarp of the East Bear Lake Fault.

Despite the strong pattern of eastward thickening of individual acoustic units, most units simply thin and pinch-out to the west. Little evidence of onlap, offlap or erosional truncation was observed in the geometry of the units on the flexural margin, and no significant angular unconformities were observed. Oblique reflections below the red clay on the western side of the profile in the CHIRP data in Fig. 5 are not present in the $3.5 \mathrm{kHz}$ or boomer data and are believed to be artifacts. Skeen (1975) interpreted a slightly undulating reflection as an unconformity near the center of the basin and described an angular unconformity between the lacustrine sequence and bedrock. We observed bedrock only on the margins of the basin and we did not observe evidence for a clear mid-basin unconformity, although our data did not penetrate as deeply as those in the previous study.
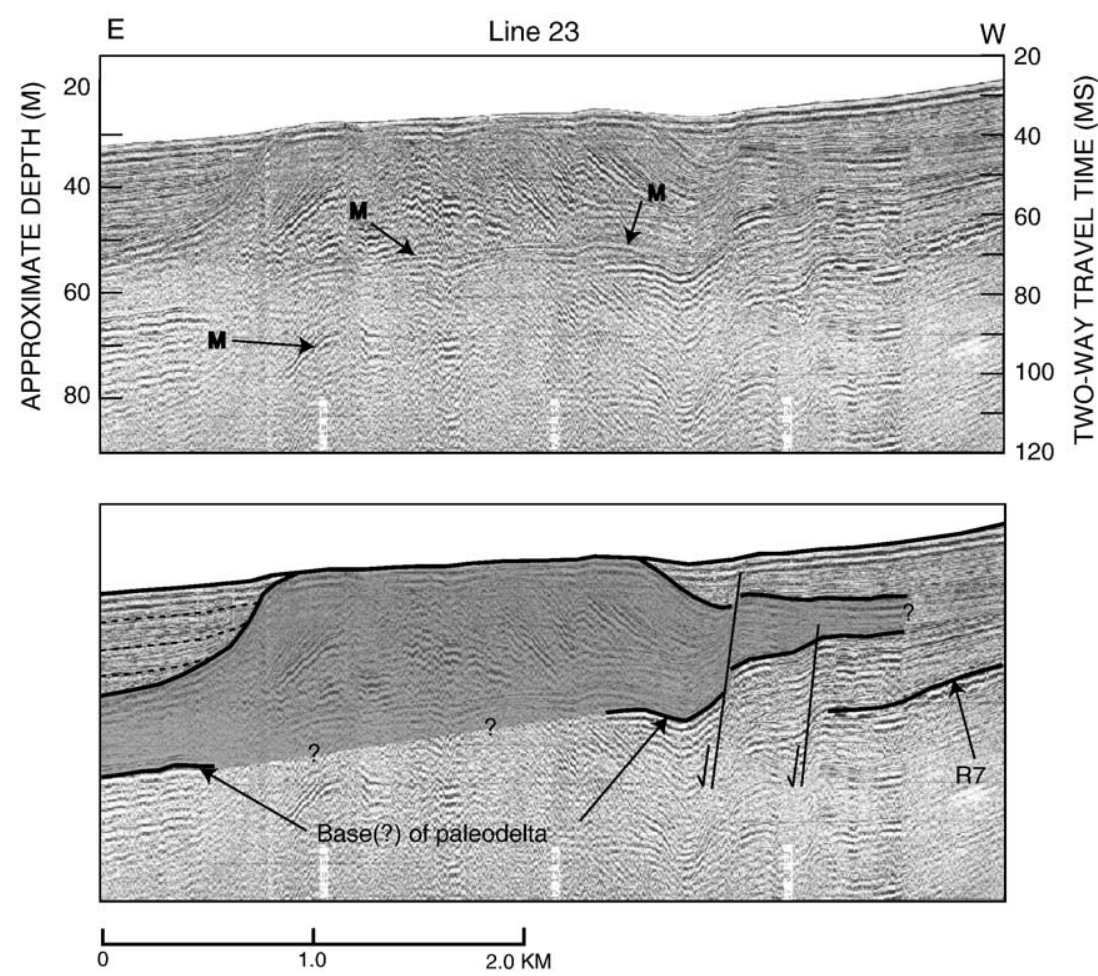

Fig. 7. East-west acoustic-reflection profile (boomer, line 23) through inferred large paleodelta in the northwest part of Bear Lake. Location shown in Fig. 1. M, multiple reflection. 


\section{Subsidence and deformation patterns}

\subsection{Sediment thickness}

The acoustic data, combined with an assumed sound velocity of $1500 \mathrm{~m} / \mathrm{s}$, allow calculation of thicknesses of sediments above individual horizons, e.g. R1, R3 and R7 (Fig. 6). On the basis of their depths in the BL00-1E drill hole (Fig. 4) and the age model for that core (Colman et al., in press), these horizons have ages of about 7, 35 and $97 \mathrm{ka}$, respectively. The overall patterns of sediment accumulation above these three horizons are similar. In each case, the accumulation pattern is asymmetric and similar in geometry to the present bathymetry of the lake. In detail, the northsouth location of depocenters adjacent to the master fault varies for the different intervals. Because of the overall configuration of the basin and because Bear Lake has no dominating point source of sediment input, the sediment accumulation patterns also probably represent the general pattern of subsidence.

The north and south ends of the lake appear transitional between the western (ramp) margin and the eastern (master fault) margin, both in terms of their configuration on acoustic profiles and their mapped sediment-thickness patterns. This pattern is probably due to decreasing displacement on the East Bear Lake Fault to the north and the south of the deepest part of the lake.

\subsection{Isolated paleodelta in the northwest corner of the basin}

An exception to the rather uniform pattern of sedimentation and eastward thickening is found in the northwestern corner of the basin. There, the uppermost lacustrine sediments are discordant with an older sedimentary unit (Figs. 7 and 8). This unit contains highamplitude, parallel reflectors that occur in discordant packages, commonly at relatively steep apparent dips (Figs. 7 and 8). The overall character and geometry suggests that the unit is an isolated paleodelta. Because even our highest frequency acoustic systems penetrate this unit to some degree, we infer that the block is composed of unconsolidated sediments, although they may be relatively coarse grained. Skeen (1975) sug-
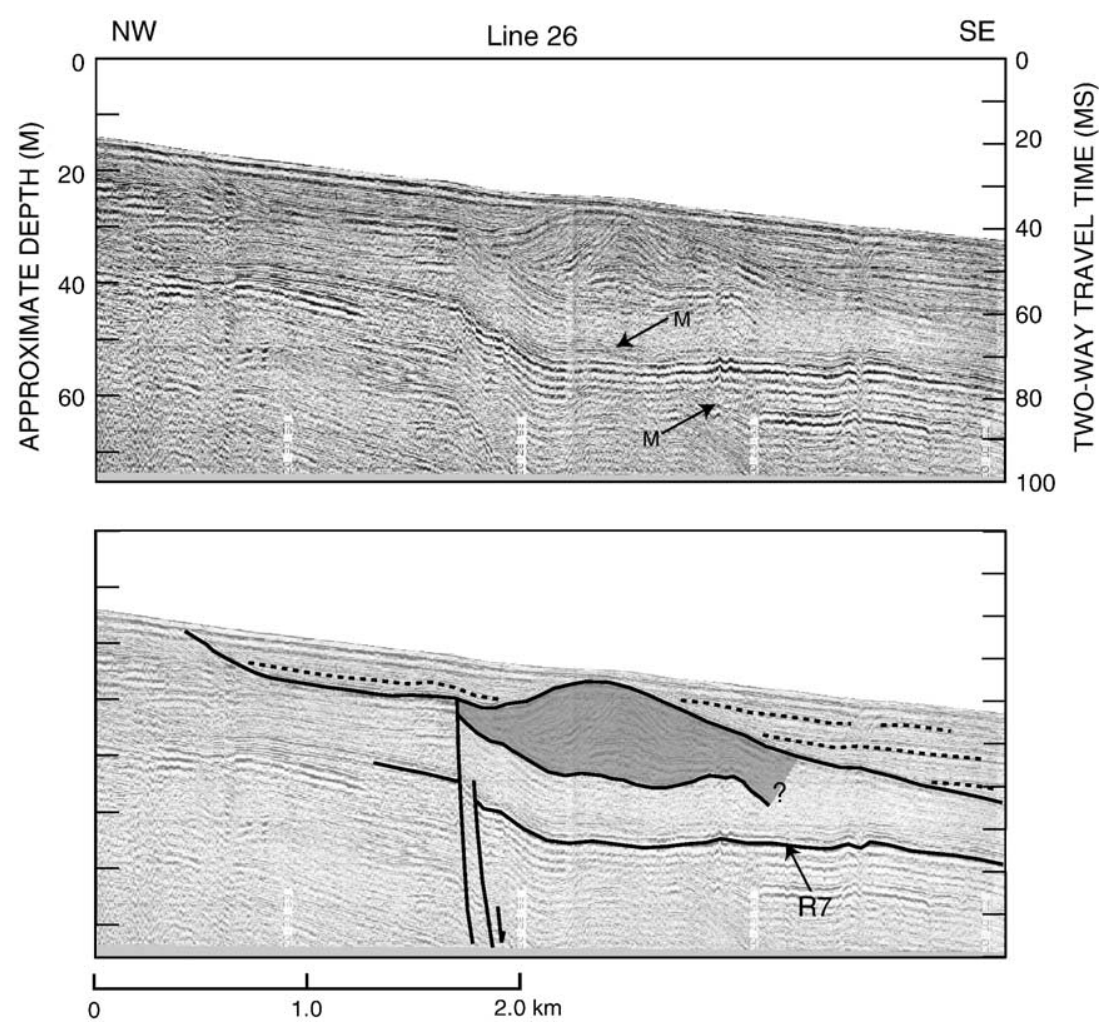

Fig. 8. Northwest-southeast acoustic-reflection profile (boomer, line 26) through large paleodelta in the northwest part of Bear Lake. Location shown in Fig. 1. Note continuous reflection from within the flanking lacustrine sequence that passes beneath the inferred delta. M, multiple reflection. 
gested the presence of a delta at the north end of the lake, but because of the different location and character of his data, it is difficult to make a comparison.

The surface of the paleodelta outcrops in a restricted pattern on the lake floor, and its flanks are buried by younger lake sediment. The surface of the outcrop of the paleodelta has little or no relief, but clear, N-S trending lineations on the lake floor within the outcrop area appear in the sidescan-sonar data (Fig. 9). These lineations may be related to former channels on the surface of the former delta. Grab samples attempted within the outcrop area were largely unsuccessful, recovering only small amounts of sand and gastropods. This suggests that the uppermost sediments in the paleodelta are relatively coarse-grained sand.

In most cases, younger lake sediments appear to simply lap onto the flanks of the paleodelta, although in some cases, an older generation of tilted or deformed lacustrine sediments appear on the flanks (Fig. 10). These relations suggest either draping of the older sediments on the paleodelta followed by onlapping deposition of younger sediments, or sliding of the older sediments into tilted and deformed positions on the flank of the paleodelta.

On most profiles, relations at depth between the paleodelta and the surrounding lake sediments are obscured, but in two cases (Figs. 7 and 8), reflections within the lacustrine sequence appear to continue beneath the paleodelta. The horizon that can be traced most clearly beneath the delta is reflector R7, which can be identified at the site of the BL00-1 drill hole (Fig. 4). Based on its depth at that site and the age model for the drill core (Colman et al., in press), R7 has an age of about $97 \mathrm{ka}$ and the delta must be somewhat younger. The sag of the reflections beneath the paleodelta (Figs. 7 and 8) may in part be due to subsidence below the paleodelta, but may also related to slower sound velocity in the coarse-grained sediments of the delta.

The imaged part of the paleodelta is about $4 \mathrm{~km}$ wide and more than $10 \mathrm{~km}$ long (Fig. 9). This substantial size suggests that the source of the delta sediment was a substantial stream, most likely the Bear River

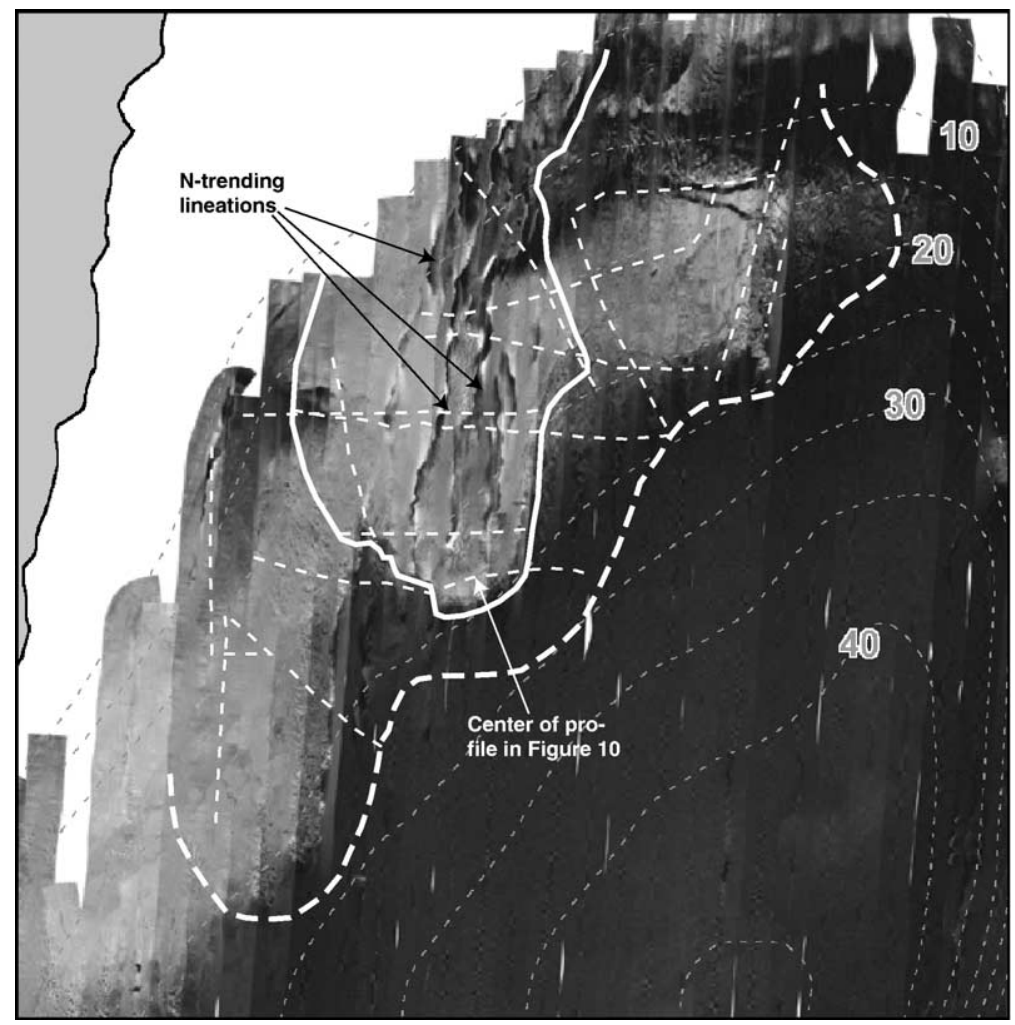

Fig. 9. Portion of sidescan-sonar mosaic showing the outcrop pattern of the inferred large paleodelta (solid heavy line) and the limits of its observed buried extent (dashed heavy line). Light dashed lines, acoustic-reflection profiles on which the paleodelta was observed. Note north-trending lineations within the outcrop area. Location shown in Fig. 2. 

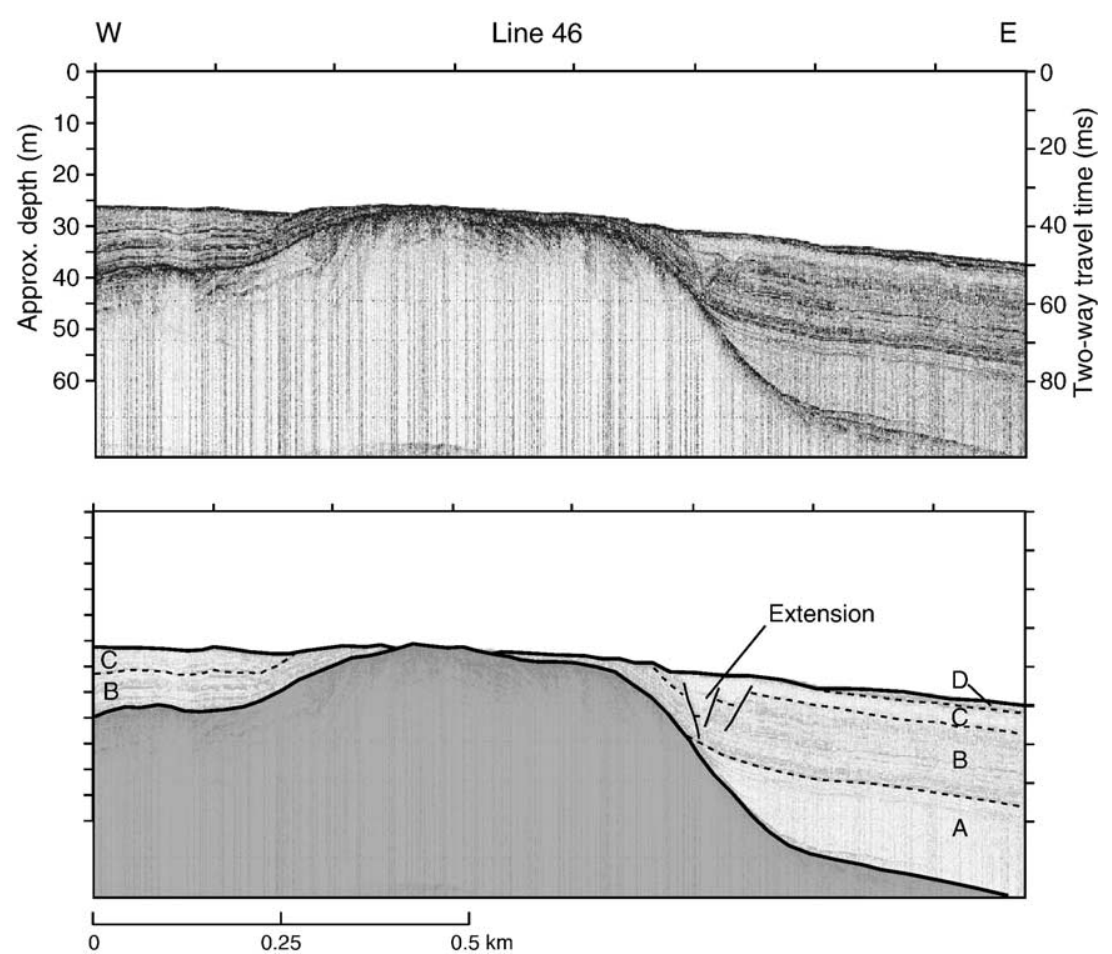

Fig. 10. Acoustic-reflection profile (CHIRP, line 46) across inferred large paleodelta. Location shown in Figs. 1 and 9. Note slight lake-floor ridges that correspond to the north-trending lineations in Fig. 9.

itself. As noted earlier, the Bear River has alternately bypassed Bear Lake and flowed into it. The distal surface of paleodelta occurs at a present depth of about $20-25 \mathrm{~m}$, presumably relating to the elevation of the lake when the delta was formed, although the delta may have been occupied more than once.
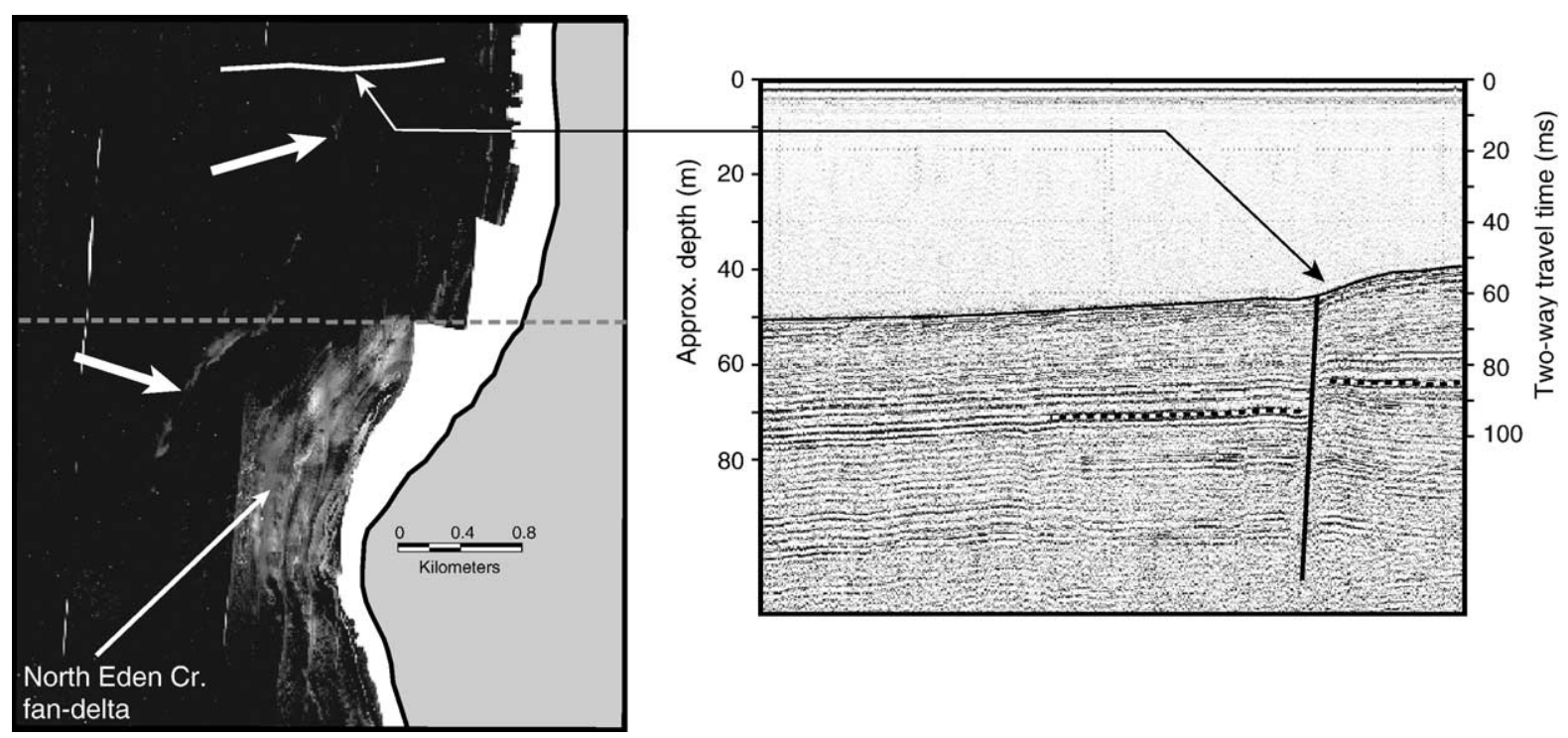

Fig. 11. Portion of sidescan-sonar mosaic and acoustic profile (boomer system) showing secondary fault west of the main East Bear Lake fault. Location of acoustic profile shown near the top of the mosaic; location of the mosaic shown in Fig. 2. Large arrows point to fault scarp. One arbitrary reflector is highlighted by a dotted line in the acoustic profile to show fault offset. 


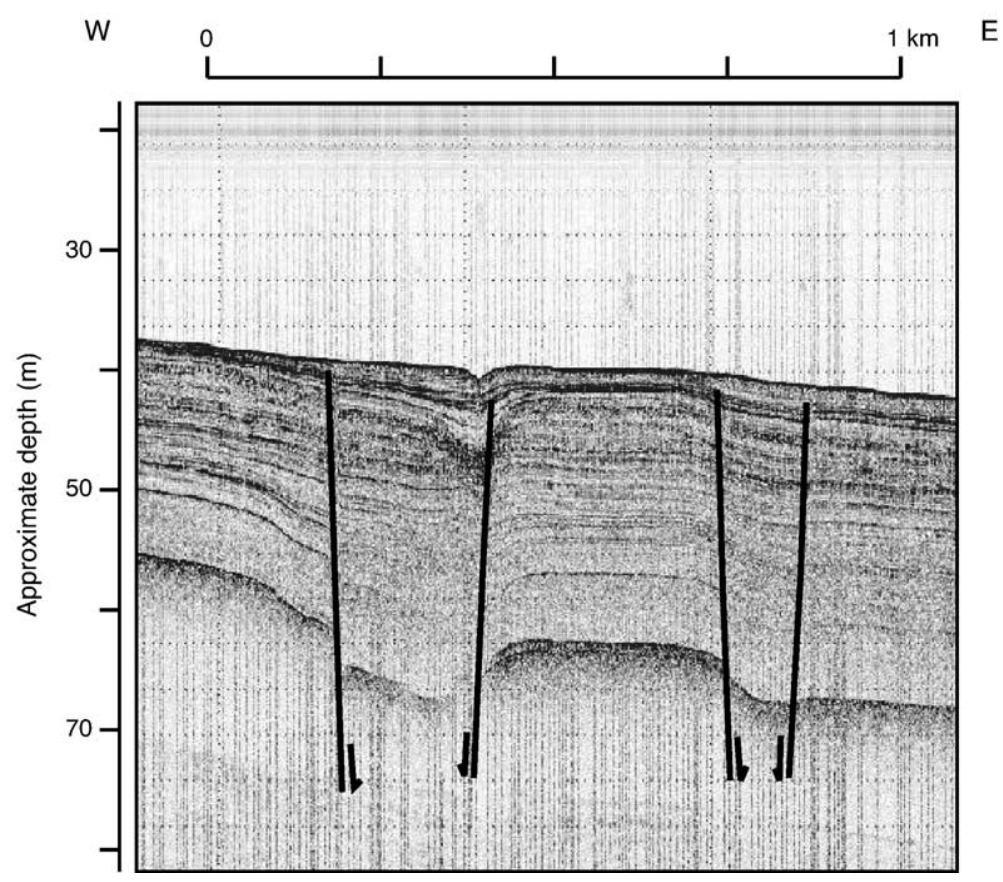

Fig. 12. Acoustic-reflection profile (CHIRP, line 40) across secondary faults forming a graben complex near the middle of the lake. Location shown in Fig. 3; faults mapped in Fig. 13.

\subsection{Faulting}

The main trace of the East Bear Lake Fault is steep and is located at or near the present shoreline, so it does not appear as such in our acoustic profiles. However, onlap and deformation of sediment against the fault scarp (Fig. 3) clearly testify to active and continuing displacement along the fault, as expected for the master fault of the half-graben.

The acoustic profiles cross several north-trending intra-basin faults . Normal faults near the steep eastern margin of the lake are both antithetic and synthetic to the East Bear Lake Fault, the major basin-bounding structure. These faults include the only one that was apparent in our sidescan-sonar data (Fig. 11). Other normal faults occur farther out into the basin (Fig. 12), one group of which form distinct north-trending secondary grabens (Fig. 13). Some of these secondary faults appear to displace the youngest sediments in the lake and to have surface expression on the lake floor. However, they do not create enough sediment or morphological contrast to appear in the sidescan-sonar data. These faults must be very young, no more than a few thousand years old.

Similar intra-basin faults appear on land and in landbased seismic-reflection data, and they are thought to represent extension due to flexing of the footwall of the
East Bear Lake Fault (Evans et al., 2003; McCalpin, 2003). Although questions have been raised about how deep they penetrate (McCalpin, 2003), they have been interpreted as significant structures, one of which was the locus of the $M 6.31884$ Bear Lake earthquake (Evans et al., 2003).

\section{Discussion and conclusions}

The acoustic-reflection and sidescan-sonar data were obtained as part of an effort to reconstruct different aspects of the paleo-environmental history of the Bear Lake region. Important parts of these reconstructions are the environments of deposition and the stratigraphic framework of the sediments, which can be derived from the geophysical data. The acoustic stratigraphy also forms a basis for correlating among the cores.

The acoustic data show stratigraphic units that are remarkably uniform and continuous. All units thicken to the east and pinch-out to the west. Few onlap, offlap or down-lap relations within the sedimentary section are apparent in the data, and most of these are on the east side of the basin, against the scarp of the East Bear Lake fault. Onlap geometries are occasionally observed against bedrock on the flexural (west) side of the basin (Fig. 14). 


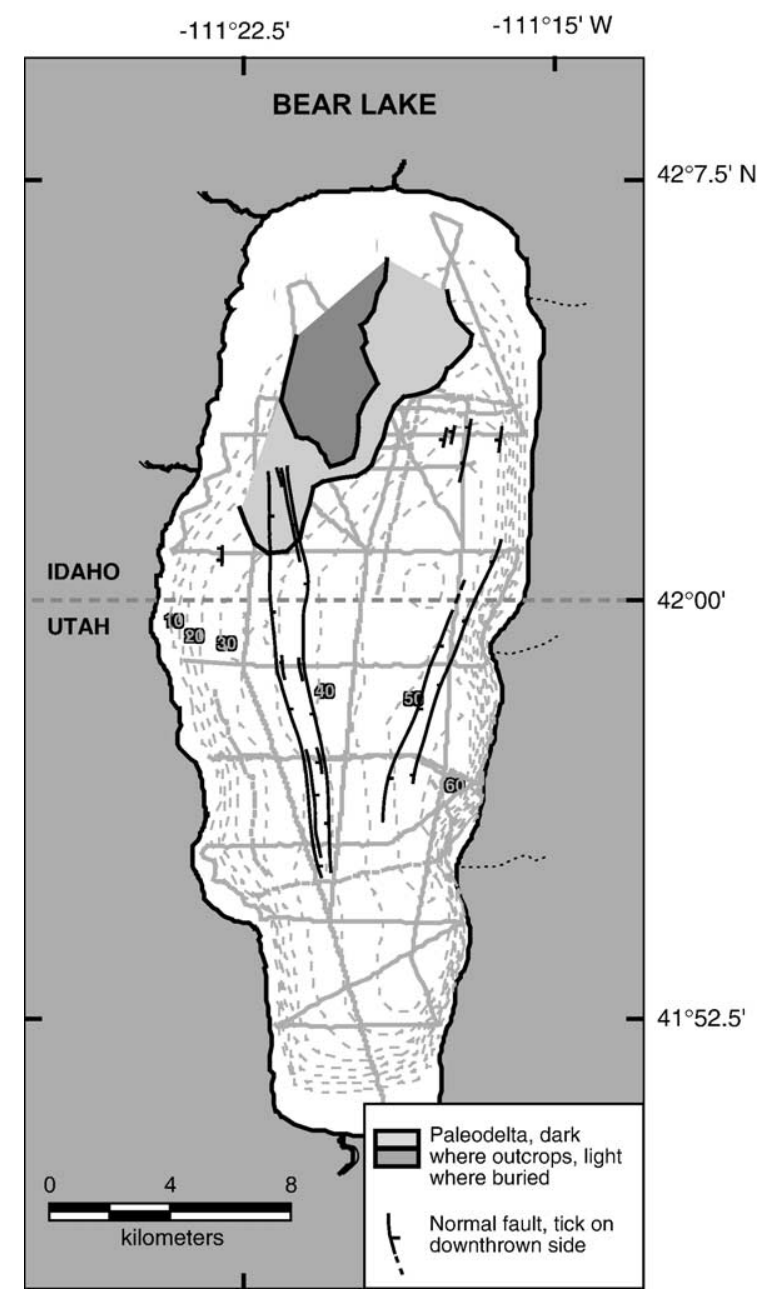

Fig. 13. Map showing the distribution of secondary faults observed on acoustic-reflection profiles.

With one exception, no erosional structures indicative of lake level significantly lower than present were observed. The single exception is a prominent step and bench, the top of which is about $4-5 \mathrm{~m}$ below present lake level (Fig. 14). This structure has a morphology suggestive of a wave-cut notch, with a lower inflection in profile at about $22-24 \mathrm{~m}$ below present lake level, possibly indicating a persistent former lake level at that depth. This is also about the depth of the top of the paleodelta discussed in the previous section, supporting the inference of a persistent or common occupation of this level. No other wave-cut structures and no other nearshore depositional features were observed in the acoustic data. If low lake stands occurred below a modern depth of about 22-24 m, they must have been so short-lived that they resulted in little or no erosional or constructional landforms.
Little modern deposition occurs in water depths less than about $30 \mathrm{~m}$ deep. The post-glacial marl thins to a few tens of $\mathrm{cm}$ in cores at or above this depth and is not resolvable in the acoustic data landward of that point. Theoretically, comparisons of the depth at which different units pinch-out might indicate differences in lake level at the time of deposition, but in practice, the pinch-outs are so gradual that their positions are difficult to define accurately.

Many aspects of the Bear Lake Basin and its fill described by Skeen (1975) are compatible with the results described here, although the more recent data suggest differences in detail. The half-graben structure of the basin, the eastward dipping and thickening sedimentary sequence, the pinch-outs of units on the western side of the basin, and the existence of shallow bedrock on the west side of the basin (Figs. 3 and 14) are well established. One possible erosion surface within the sedimentary sequence suggested by Skeen (1975) is deeper than the penetration of our acoustic systems; within our data, all major deep-water units appear to be conformable.

Using his seismic data and an assumed value for sound velocity and sedimentation rates, Skeen (1975) estimated a thickness of the lacustrine sediments in the extensional basin of $387 \mathrm{~m}$ and an age of 325-775 ka for the base of the lacustrine sequence. The bases of sedimentary sequences are difficult to define in highresolution acoustic data and the reflection interpreted by Skeen (1975) may not be bedrock. Certainly, more recent land-based deep seismic data suggest that the basin is much deeper, on the order of $3 \mathrm{~km}$ (Evans et al., 2003). Assuming this $3 \mathrm{~km}$ sediment thickness and the sedimentation rate of $0.5 \mathrm{~m} / \mathrm{kyr}$ for the 2000 drill core (Colman et al., in press), near the center of the present lake, then the basin and its oldest sediments are at least 6 million years old.

\section{Acknowledgements}

D.R. Nichols provided technical assistance and helped collect the acoustic data in both 1997 and 2002, aided in 2002 by J. Denny, D. Wiese and R. Goldberg. J. Denny acquired and processed all of the sidescan-sonar images. Logistical help was provided by the Utah Department of Natural Resources, Division of Wildlife Resources (Bryce Nielson and Scott Tarentino), Utah State Parks personnel, and C. Lueke and W. Wurtzbaugh of Utah State University. W.P. Dillon, T.C. Johnson, R.N. Oldale and C.A. Scholz provided helpful reviews of earlier versions of the paper. 


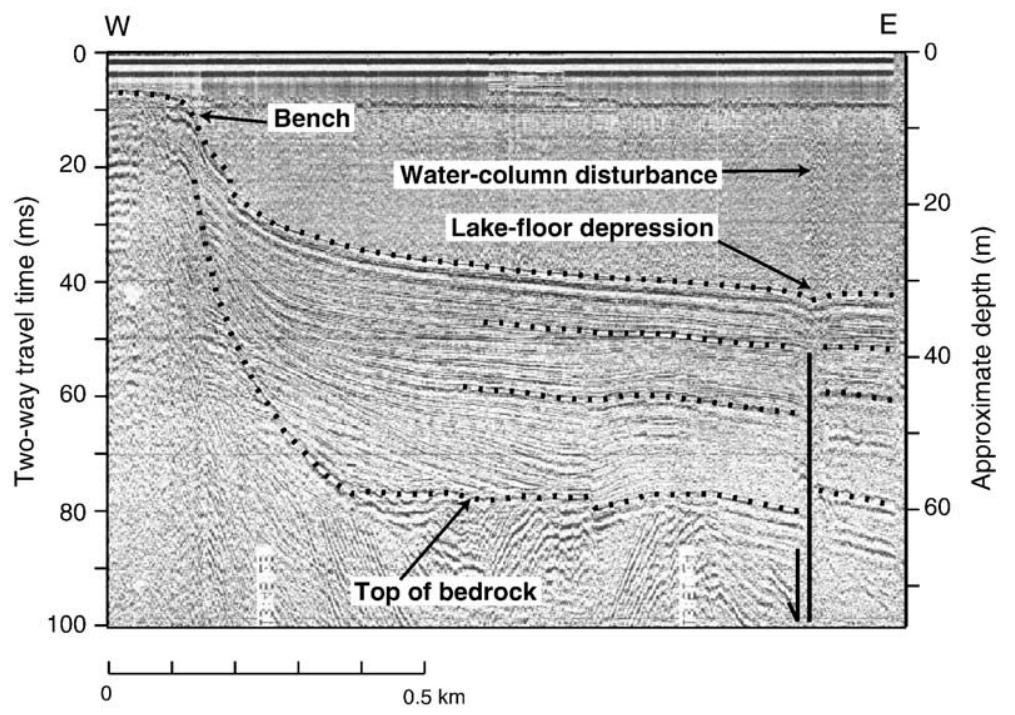

Fig. 14. Acoustic profile (boomer system) near the western end of line 28 showing erosional bench. A lake floor depression and water column disturbance, possibly related to a sublacustrine spring above a deep-seated fault, are also shown. The lake floor, top of bedrock and two horizons in between are marked by dotted lines. Location shown in Fig. 3.

\section{References}

Colman, S.M., Karabanov, E.B., Nelson, C.H., 2003. Quaternary sedimentation and subsidence history of Lake Baikal, Siberia, based on seismic stratigraphy and coring. Journal of Sedimentary Research 73 (6), 941-956.

Colman, S.M. et al., in press. Age models for a continuous 250-kyr Quaternary lacustrine record from Bear Lake, Utah-Idaho. Quaternary Science Reviews.

Dean, W. et al., 2002. Progress in global lake drilling holds potential for global change research. EOS, Transactions of the American Geophysical Union, 83(9): 85, 90-91.

Dean, W.E., et al., 2006 - this volume. Unusual Holocene and late Pleistocene carbonate sedimentation in Bear Lake, Utah-Idaho, U.S.A. Sedimentary Geology 185, $93-112$. doi:10.1016/j.sedgeo. 2005.11.016.

Denny, J.F., Colman, S.M., 2003. Geophysical Surveys of Bear Lake, Utah-Idaho, September, 2002. U.S. Geological Survey Open-File Report 03-150.

Dixon, J.S., 1982. Regional structural synthesis, Wyoming salient of the western Overthrust Belt. American Association of Petroleum Geologists Bulletin 66, 1560-1581.

Evans, J.P., Martindale, D.C., Kendrick Jr., R.D., 2003. Geologic setting of the 1884 Bear Lake, Idaho, earthquake: rupture in the hanging wall of a basin and range normal fault revealed by historical and geological analyses. Bulletin of the Seismological Society of America 93, 1621-1632.

Johnson, T.C., Halfman, J.D., Rosendahl, B.R., Lister, G.S., 1987. Climatic and tectonic effects on sedimentation in a rift-valley lake-evidence from high-resolution seismic profiles, Lake Turkana, Kenya. Geological Society of America Bulletin 98, 439-447.
Kaliser, B.N., 1972. Environmental geology of the Bear Lake area, Utah and Idaho. Utah Geological and Mineral Survey Bulletin 28 (56 pp.).

Laabs, B.J.C., Kaufman, D.S., 2003. Quaternary highstands in Bear Lake Valley, Utah and Idaho. Geological Society of America Bulletin 115 (4), 463-478.

Lezzar, K.E., et al., 1996. New seismic stratigraphy and Late Tertiary history of the North Tanganyika basin, East Africa Rift system, deduced from multichannel and high-resolution reflection seismic data and piston core evidence. Basin Research 8, 1-26.

McCalpin, J.P., 1993. Neotectonics of the northeastern basin and range margin, western USA. Zeitschrift fur Geomorphologie 94, $137-157$.

McCalpin, J.P., 2003. Neotectonics of Bear Lake Valley, Utah and Idaho: a preliminary assessment. Utah Geological Survey, Miscellaneous Publication 03-4, Salt Lake City, Utah. 43 pp.

Moore, T.C., Klitgord, K.D., Golmshtok, A.J., Weber, E., 1997. Sedimentation and subsidence patterns in the central and north basins of Lake Baikal from seismic stratigraphy. Geological Society of America Bulletin 109, 746-766.

Scholz, C.A., Hutchinson, D.R., 2000. Stratigraphic and structural evolution of the Selenga Delta accommodation zone, Lake Baikal Rift, Siberia. International Journal of Earth Science 89, 212-228.

Scholz, C.A., Johnson, T.C., McGill, J.W., 1993. Deltaic sedimentation in a rift valley lake: new seismic reflection data from Lake Malawi (Nyasa), East Africa. Geology 21, 395-398.

Skeen, R.C., 1975. A reflection seismic study of the subsurface structure and sediments of Bear Lake, Utah-Idaho. Unpublished Senior Thesis, University of Utah, Salt Lake City, Utah. 24 pp.

Williams, J.S., Willard, A.D., Parker, V., 1962. Recent geological history of Bear Lake Valley, Utah and Idaho. American Journal of Science 260, 24-36. 